\title{
ANALISIS KONDISI FUNGSIONAL JALAN DENGAN METODE PSI DAN RCI SERTA PREDIKSI SISA UMUR PERKERASAN JALAN STUDI KASUS : JALAN BATAS KOTA WATES - MILIR
}

\author{
Novia Ayu Nugraheni ${ }^{1)}$, Ary Setyawan ${ }^{2)}$, Suryoto ${ }^{3)}$ \\ ${ }^{1)}$ Mahasiswa Program S1 Teknik Sipil Universitas Sebelas Maret \\ 2) 3) Pengajar Program studi Teknik Sipil, Universitas Sebelas Maret \\ Jalan Ir.Sutami No.36A Surakarta 57126.Telp.0271647069. Email : noviayunugraheni@student.uns.ac.id
}

\begin{abstract}
Economic growth has an impact on the need for increased movement of goods and services by land. This also occurs on the South Line of Java Island, especially on the Wates City Border - Milir which is damaged faster than the age of the plan. The first step to prevent the decline of road conditions is to conduct inspections to assess the road conditions. From the value of road conditions can be used to predict the remaining life of pavement. This study aims to assess the fuctional condition of the road based on Present Serviceability Index (PSI) and Road Condition Index (RCI), and also predict the remaining life of pavement on City Border of Wates - Milir road.

In this study, the road condition is assessed by the analysis of the road functional condition based on the level of the road flatness (International Roughness Index, IRI) obtained from P2JN Yogyakarta data. Parameters of road conditions analyzed include Present Serviceability Index (PSI) for road service function and Road Condition Index (RCI) for surface conditions. As for the remaining life of pavement prediction using daily traffic data with AASHTO 1993 Method from the same data source.

Based on the assessment of road condition, the average value of PSI 1.79 indicated poor service function, while the average value of RCI 7.51 showed excellent surface condition. The results of the analysis on the remaining life of pavement for 2017, road pavement still has a remaining life percentage of $14,35 \%$ and the road predicted will end in year 6 is in 2018.
\end{abstract}

Keywords: PSI, RCI, Remaining Life of Pavement.

\begin{abstract}
Abstrak
Pertumbuhan ekonomi memberi dampak pada meningkatnya kebutuhan pergerakan barang dan jasa melalui jalur darat. Ini juga terjadi pada Jalur Selatan Pulau Jawa terutama di ruas Batas Kota Wates - Milir yang mengalami kerusakan lebih cepat dari umur rencana. Langkah awal untuk mencegah penurunan kondisi jalan tersebut adalah dengan melakukan inspeksi untuk menilai kondisi jalan. Dari nilai kondisi jalan tersebut selanjutnya dapat digunakan untuk memprediksi sisa umur perkerasan. Penelitian ini bertujuan untuk menilai kondisi fungsional jalan berdasarkan indeks permukaan (PSI) dan indeks kondisi jalan (RCI), serta memprediksi sisa umur perkerasan pada ruas jalan Batas Kota Wates - Milir.

Pada penelitian ini dilakukan penilaian kondisi jalan dengan analisis nilai kondisi fungsional jalan berdasarkan tingkat kerataan jalan (International Roughness Index, IRI) yang didapatkan dari data P2JN Yogyakarta. Parameter kondisi jalan yang dianalisis antara lain Indeks Permukaan (Present Serviceability Index, PSI) untuk fungsi pelayanan jalan dan Indeks Kondisi Jalan (Road Condition Index, RCI) untuk kondisi permukaan. Sedangkan untuk prediksi sisa umur perkerasan menggunakan data lalu lintas dengan Metode AASHTO 1993 dari sumber data yang sama.

Berdasarkan analisis penilaian kondisi jalan didapatkan hasil rata-rata nilai PSI sebesar 1,79 yang menunjukkan fungsi pelayanan kurang, sedangkan rata-rata nilai RCI sebesar 7,51 menunjukkan kondisi permukaan yang sangat baik. Hasil analisis terhadap umur perkerasan jalan menyatakan bahwa untuk tahun 2017, perkerasan jalan masih memiliki porsentase umur sisa sebesar 14,35\% dan umur sisa jalan diprediksi akan berakhir pada tahun ke 6 yaitu pada tahun 2018.
\end{abstract}


Kata Kunci: PSI, RCI, Sisa Umur Perkerasan.

\section{PENDAHULUAN}

Jalan nasional merupakan jalan penghubung antar provinsi untuk memperlancar transportasi nasional dan menjadi tanggung jawab negara. Jalan Batas Kota Wates-Milir termasuk dalam ruas jalan Nasional Rute 3 yang terletak di Kabupaten Kulon Progo dengan kelas jalan Arteri I. Seiring dengan meningkatnya kebutuhan pergerakan barang dan jasa terutama untuk transportasi darat mengakibatkan kerusakan jalan akan lebih cepat dari umur rencana. Kerusakan jalan yang telah terjadi pada ruas jalan Batas Kota Wates-Milir diantaranya retak, alur, dan lubang. Faktor penyebab kerusakan jalan tersebut dapat disebabkan karena jumlah kendaraan yang melintas melebihi jumlah lalu lintas rencana. Langkah awal untuk menginspeksi penurunan tingkat pelayanan jalan tersebut salah satunya dengan melakukan penilaian terhadap kondisi jalan dengan analisis kondisi fungsional jalan berdasarkan tingkat kerataan jalan.

Nilai kerataan jalan (International Roughness Index, IRI) merupakan salah satu fungsi pelayanan (functional performance) dari suatu perkerasan jalan yang sangat berpengaruh pada kenyamanan pengemudi (riding quality). Dua parameter kondisi pelayanan yang dianalisis adalah Indeks Permukaan (Present Serviceability Index, PSI) dan Indeks Kondisi Jalan (Road Condition Index, RCI).

Indeks Permukaan (IP) atau Present Serviceability Index (PSI) diperkenalkan oleh AASHTO berdasarkan pengamatan kondisi jalan yang meliputi kerusakan-kerusakan seperti retak, alur, lubang, lendutan pada lajur roda, dan sebagainya. Dari nilai PSI akan didapatkan fungsi pelayanan jalan dengan nilai IP untuk jalan baru dibuka adalah 4,2 sedangkan IP aakhir umur rencana untuk jalan arteri adalah 2,0. Sedangkan Indeks Kondisi Jalan (Road Condition Index, RCI) adalah skala tingkat kenyamanan jalan yang dapat diperoleh dari pengukuran alat Roughometer maupun secara visual. Dari nilai RCI akan didapatkan kondisi permukaan jalan.

Akibat kondisi ruas jalan Batas Kota Wates-Milir saat ini banyak mengalani kerusakan setelah dilakukan perbaikan (overlay) pada tahun 2012 lalu. Hal ini menyebabkan ketidakpastian terhadap sisa umur layan dari perkerasan. Untuk memprediksi sisa umur perkerasan berakhir, maka dilakukan prediksi sisa umur perkerasan menggunakan data lalu lintas dengan Metode AASHTO 1993.

\section{TINJAUAN PUSTAKA}

Utama, Rangga M., dan Ida Farida (2016) melakukan evaluasi kondisi struktural pada jalan berdasarkan hubungan antara ketidakrataan permukaan jalan (IRI) dan indeks kondisi jalan (RCI) pada Ruas Jalan Selajambe-Cibeet sepanjang $28,591 \mathrm{~km}$. Dari hasil analisis didapat nilai IRI $=4,00 \mathrm{~m} / \mathrm{km}$, IP $/$ PSI $=1,824$ dan $\mathrm{RCI}=6,87$. Artinya ruas jalan memiliki kondisi yang baik (RCI 6-7), namun fungsi pelayanan kurang baik (nilai IP/PSI < 2). Dengan tingkat kerusakan jalan rata-rata adalah 5,130\%.

Purwingga, Enji P. (2016) melakukan evaluasi kerusakan dini akibat beban berlebih pada perkerasan lentur untuk Ruas Jalan Kartasura-Batas Kota Klaten Km 11+900 - Km 12+300 dari arah Jogja ke Solo. Metode yang digunakan dengan melakukan pemeriksaan perkerasan lentur, pemeriksaan jembatan timbang, serta pemeriksaan jenis kerusakan jalan akibat beban berlebih. Pengolahan data yang didapat antara lain menyatakan ruas jalan mengalami overloading, menghitung umur sisa perkerasan lentur akibat beban berlebih dengan metode AASHTO 1993. Berdasarkan perhitungan terdapat penyusutan umur sisa perkerasan antara keadaan normal dengan sisa perkerasan yang terkena dampak overload sebesar 14,75\% dan umur rencana jalan akan berakhir pada tahun ke-6. Solusi untuk meminimalisisr kerusakan jalan akibat beban berlebih yaitu: mengganti jalan dengan dengan perkerasan kaku, perlu dibuat jembatan timbang dan dibuat peraturan yang tegas.

\section{LANDASAN TEORI}

\section{Kinerja Perkerasan}

Kinerja perkerasan menurut Suwardo (2004) meliputi keamanan/kekuatan perkerasan (structural pavement), maupun 
fungsi (functional performance) dinyatakan dengan Indeks Permukaan (IP) atau Present Serviceability Index (PSI) dan Indeks Kondisi Jalan (Road Condition Index = RCI).

Menurut Suherman (2008) secara umum kinerja perkerasan dapat ditentukan dengan dua cara yaitu cara objektif dan cara subjektif. Dengan cara objektif diperoleh dari suatu pengukuran menggunakan alat seperti Roughometer NAASRA contohnya International Roughness Index (IRI), sedangkan dengan cara subjektif didasarkan kepada hasil pengamatan beberapa orang ahli misal Road Condition Index (RCI).

\section{Kerusakan Perkerasan}

Kerusakan jalan dapat dibedakan atas retak (cracking), distorsi (distortion) atau perubahan bentuk, cacat permukaan (disintegration), pengausan (polished aggregate), kegemukan (bleeding or flushing), dan penurunan pada bekas penanaman utilitas (utility cut depression).

\section{International Roughness Index (IRI)}

International Roughness Index (IRI) atau ketidakrataan permukaan adalah parameter ketidakrataan yang dihitung dari jumlah kumulatif naik turunnya permukaan arah profil memanjang dibagi dengan jarak/panjang permukaan yang diukur. Nilai IRI merupakan output dari alat survei canggih yaitu NAASRA Ronghnessmeter yang digunakan sebagai indikator utama dalam menentukan nilai kondisi fungsional jalan yang sangat berpengaruh pada kenyamanan (riding quality) pada ruas Jalan Nasional.

\section{Present Serviceability Index (PSI)}

Indeks Permukaan (IP) atau Present Serviceability Index (PSI) diperkenalkan oleh AASHTO yang diperoleh dari pengamatan kondisi jalan meliputi kerusakan-kerusakan seperti retak (crack), alur (rutting), lubang (pothole), lendutan pada lajur roda, kekasaran permukaan, dan lain sebagainya yang terjadi selama umur pelayanan. Dikutip dari NHCRP (2001) IP dinyatakan sebagai fungsi dari IRI untuk perkerasan beraspal melalui persamaan berikut:

PSI $=5-0,2937 \mathrm{X}^{4}+1,1771 \mathrm{X}^{3}-1,4045 \mathrm{X}^{2}-1,5803 \mathrm{X}$

Dengan: $\quad X \quad=\log (1+S V)$

$$
\mathrm{SV}=\text { Slope Variance }=2,2704 \mathrm{IRI}^{2}
$$

PSI $=$ Present Serviceability Index

IRI = International Roughness Index, $\mathrm{m} / \mathrm{km}$

Indeks Permukaan bervariasi dari angka $0-5$ yang menunjukkan fungsi pelayanan seperti pada Tabel 1 Indeks Permukaan sebagai berikut.

Tabel 1 Indeks Permukaan

\begin{tabular}{|c|c|l|}
\hline No. & Indeks Permukaan (IP) & \multicolumn{1}{c|}{ Fungsi Pelayanan } \\
\hline \hline 1 & $4-5$ & Sangat baik \\
\hline 2 & $3-4$ & Baik \\
\hline 3 & $2-3$ & Cukup \\
\hline 4 & $1-2$ & Kurang \\
\hline 5 & $0-1$ & Sangat Kurang \\
\hline
\end{tabular}

Sumber: Silvia Sukirman (1999)

\section{Road Condition Index (RCI)}

Indeks Kondisi Jalan (Road Condition Index, RCI) adalah skala dari tingkat kenyamanan atau kinerja dari jalan, dapat diperoleh sebagai hasil dari pengukuran dengan alat Roughometer ataupun secara visual. Menurut Silvia Sukirman (1999) korelasi antara RCI dan IRI untuk Indonesia adalah sebagai berikut.

$\mathrm{RCI}=10 * \operatorname{Exp}\left(-0,0501 * \mathrm{IRI}^{1,220920}\right)$...

Skala RCI bervariasi dari 2 - 10, dengan pengertian seperti pada Tabel 2 Kondisi Permukaan secara Visual sebagai berikut. 
Tabel 2 Kondisi Permukaan secara Visual

\begin{tabular}{|c|l|}
\hline RCI & \multicolumn{1}{|c|}{ Kondisi Permukaan Jalan Secara Visual } \\
\hline \hline $8-10$ & Sangat rata dan teratur \\
\hline $7-8$ & Sangat baik, umumnya rata \\
\hline $6-7$ & Baik \\
\hline $5-6$ & Cukup, sedikit/tidak ada lubang, tetapi permukaan jalan tidak rata \\
\hline $4-5$ & Jelek, kadang-kadang ada lubang, permukaan jalan tidak rata \\
\hline $3-4$ & Rusak, bergelombang, banyak lubang \\
\hline $2-3$ & Rusak berat, banyak lubang dan seluruh daerah perkerasan hancur \\
\hline$\leq 2$ & Tidak dapat dilalui, kecuali dengan 4WD jeep \\
\hline
\end{tabular}

Sumber: Silvia Sukirman (1999)

\section{Sisa Umur Perkerasan Jalan (Remaining Life)}

Umur sisa perkerasan merupakan konsep kerusakan kelelahan aspal yang diakibatkan oleh beban repetisi kendaraan secara berulang-ulang yang merusak perkerasan dan mengurangi kapasitas beban repetisi yang dapat ditanggung oléh suatu perkerasan hingga perkerasan tersebut mengalami keruntuhan (failure). Ketidakpastian umur layan akan mempengaruhi integritas perencanaan yang menjadi rujukan, serta mempengaruhi rencana prioritas penanganan rehabilitasi jalan jangka panjang di suatu ruas jalan tertentu. Metode yang dapat digunakan untuk melakukan prediksi terhadap umur sisa perkerasan jalan salah satunya adalah Metode AASHTO 1993.

1) Umur Rencana, untuk perkerasan lentur jalan baru adalah 20 tahun dan untuk peningkatan jalan 10 tahun.

2) Faktor Pertumbuhan Lalu Lintas, dihitung berdasarkan rumus:

$$
i \quad=\left(\frac{\mathrm{LHR}_{\mathrm{n}}}{\mathrm{LHR}_{1}}\right)^{\frac{1}{\mathrm{n}}}-1 \text {. }
$$

Dengan:

$i \quad=$ Faktor pertumbuhan

$\mathrm{n} \quad=$ Tahun ke-n

$\mathrm{LHR}_{1}=$ LHR tahun awal

$\mathrm{LHR}_{\mathrm{n}}=$ LHR tahun ke-n

Sehingga LHR pada umur rencana didapatkan dengan rumus:

$\operatorname{LHR}_{\mathrm{n}}=\mathrm{LHR}_{1} \times(1+i)^{\mathrm{n}}$

3) Vehicle Damage Factor (VDF) menggambarkan seberapa besar pengaruh suatu kendaraan terhadap perkerasan apabila melintas di atas lapisan perkerasan. Nilai VDF Standar mengacu pada Manual Desain Perkerasan Jalan Bina Marga Tahun 2013 seperti pada Tabel 3 berikut.

Tabel 3 Nilai VDF Standar

\begin{tabular}{|c|c|l|c|c|}
\hline No & Klas & \multicolumn{1}{|c|}{ Jenis } & Sumbu & VDF \\
\hline \hline 1 & 1 & Sepeda Motor & 1,1 & 0,00 \\
\hline 2 & 2.3 .4 & Sedan/Angkot/pickup/station wagon & 1,1 & 0,00 \\
\hline 3 & $5 . \mathrm{a}$ & Bus Kecil & 1,2 & 0,30 \\
\hline 4 & $5 . \mathrm{b}$ & Bus Besar & 1,2 & 1,00 \\
\hline 5 & 6,1 & Truk 2 Sumbu Cargo Ringan & 1,1 & 0,30 \\
\hline
\end{tabular}




\begin{tabular}{|c|c|l|c|c|}
\hline No & Klas & \multicolumn{1}{|c|}{ Jenis } & Sumbu & VDF \\
\hline \hline 6 & 6,2 & Truk 2 Sumbu Ringan & 1,2 & 0,80 \\
\hline 7 & 7,1 & Truk 2 Sumbu Cargo Sedang & 1,2 & 0,70 \\
\hline 8 & 7,2 & Truk 2 Sumbu Sedang & 1,2 & 1,60 \\
\hline 9 & 8,1 & Truk 2 Sumbu Berat & 1,2 & 0,90 \\
\hline 10 & 8,2 & Truk 2 Sumbu Berat & 1,2 & 7,30 \\
\hline 11 & 9,1 & Truk 3 Sumbu Ringan & 1,22 & 7,60 \\
\hline 12 & 9,2 & Truk 3 Sumbu Sedang & 1,22 & 28,10 \\
\hline 13 & 9,3 & Truk 3 Sumbu Berat & 1.1 .2 & 28,90 \\
\hline 14 & 10 & Truk 2 Sumbu dan Trailer Penarik 2 Sumbu & $1.2-2.2$ & 36,90 \\
\hline 15 & 11 & Truk 4 Sumbu-Trailer & $1.2-22$ & 13,60 \\
\hline 16 & 12 & Truk 5 Sumbu-Trailer & $1.22-22$ & 19,00 \\
\hline 17 & 13 & Truk 5 Sumbu-Trailer & $1.2-222$ & 30,30 \\
\hline 18 & 14 & Truk 6 Sumbu-Trailer & $1.22-222$ & 41,60 \\
\hline
\end{tabular}

Sumber: Manual Desain Perkerasan Jalan Nomor 02/M/BM/2013

4) Beban Gandar Standar Kumulatif $\left(W_{t}\right)$

Lalu lintas pada lajur rencana diberikan dalam bentuk kumulatif beban gandar standar (Wt).

ESAL $=\sum\left(\right.$ kendaraan $_{\mathrm{i}} /$ hari $) \times \mathrm{E}_{1}$

$\mathrm{W}_{\mathrm{t}} \quad=\mathrm{ESAL} \times \mathrm{D}_{\mathrm{D}} \times \mathrm{D}_{\mathrm{L}} \times 365$

Keterangan:

ESAL = Perhitungan Repetisi Beban Lalu Lintas

$\mathrm{E}_{\mathrm{i}} \quad=$ Angka ekivalen beban kendaraan $\mathrm{i}$

$\mathrm{D}_{\mathrm{D}} \quad=$ Faktor distribusi arah (diambil 0,5)

$\mathrm{D}_{\mathrm{L}} \quad=$ Faktor distribusi lajur (2 lajur $\left.=0,8\right)$

$\mathrm{W}_{18} \quad=$ Beban gandar standar kumulatif

Umur sisa atau Remaining Life (RL) yang dipengaruhi oleh beban lalu lintas terhadap pertambahan waktu dapat dihitung dengan persamaan:

RL $\quad=100\left[1-\left(\frac{\mathrm{N}_{\mathrm{p}}}{\mathrm{N}_{2}}\right)\right]$

Dengan:

RL = Umur sisa perkerasan atau Remaining life (\%)

$\mathrm{N}_{\mathrm{p}} \quad=$ Kumulatif ESAL pada akhir tahun ke-n

$\mathrm{N}_{2} \quad=$ Kumulatif ESAL pada akhir tahun rencana untuk jalan arteri

\section{METODE PENELITIAN}

Penelitian ini menggunakan data sekunder berupa nilai IRI dan data lalu lintas yang didapatkan dari survei Satker P2JN Daerah Istimewa Yogyakarta pada Ruas Batas Kota Wates-Milir Sta. 0+000 s/d Sta. 3+300. Analisis kondisi fungsional jalan menggunakan data nilai IRI yang meliputi analisis fungsi pelayanan dengan metode PSI serta analisis kondisi permukaan jalan dengan metode RCI. Sedangkan untuk mengetahui umur sisa perkerasan menggunakan data lalu lintas yang dianalisis dengan Metode AASHTO 1993.

\section{Tahap Penelitian}

Tahapan yang dilakukan dalam penelitian ini dapat dilihat pada Gambar 1 Diagram Alir Penelitian berikut ini. 


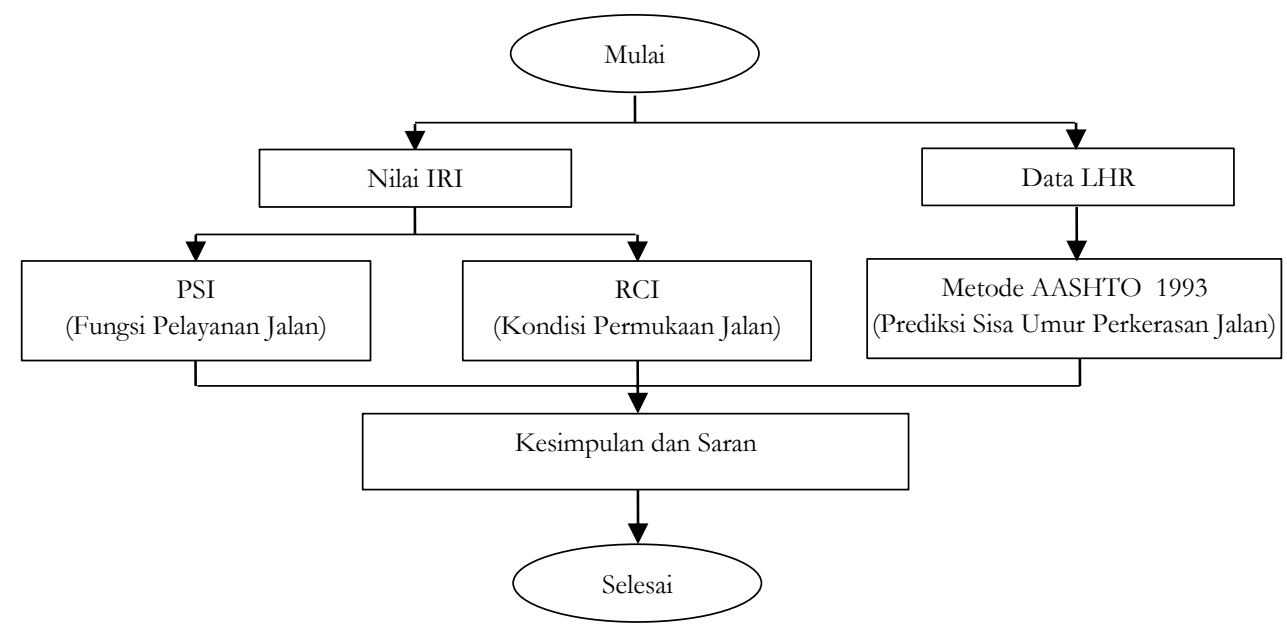

Gambar 1 Diagram Alir Penelitian

\section{HASIL DAN PEMBAHASAN}

\section{Analisis Kondisi Fungsional Jalan}

Kondisi fungsional jalan yang dianalisis adalah fungsi pelayanan dan kondisi permukaan jalan. Analisis fungsi pelayanan jalan dilakukan dengan menghitung nilai Present Serviceability Index (PSI) dengan contoh perhitungan sebagai berikut. Untuk Sta 0+000 s.d. 0+100 dengan nilai IRI = 3,4 menggunakan persamaan [1] dengan contoh perhitungan sebagai berikut.

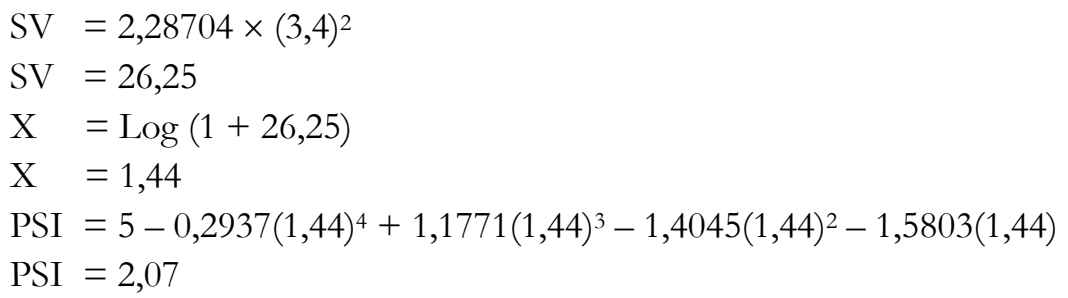

Dengan nilai PSI $=2,07$ berdasarkan Tabel 1 Indeks Permukaan menunjukkan kondisi permukaan "cukup". Selanjutnya hasil perhitungan nilai PSI secara keseluruhan dapat dilihat pada Tabel 4 di bawah.

Sedangkan untuk analisis kondisi permukaan jalan dilakukan dengan menghitung nilai Road Condition Index (RCI) dengan contoh perhitungan sebagai berikut.

Untuk Sta 0+000 s.d. $0+100$ dengan nilai IRI $=3,4$ menggunakan persamaan [2] sebagai berikut.

$\mathrm{RCI}=10 \times \operatorname{Exp}\left(-0,0501 \times(3,4)^{1,220920}\right)$

$\mathrm{RCI}=8,00$

Dengan nilai RCI $=8,00$ berdasarkan Tabel 2 Kondisi Permukaan secara Visual menunjukkan kondisi permukaan "sangat baik, umumnya rata". Selanjutnya hasil perhitungan nilai RCI secara keseluruhan dapat dilihat pada Tabel 4 Hasil Analisis Kondisi Fungsional Jalan berikut ini.

Tabel 4 Hasil Analisis Kondisi Fungsional Jalan

\begin{tabular}{|c|c|c|c|l|c|l|c|l|}
\hline \multirow{2}{*}{ No. } & \multicolumn{2}{|c|}{ Sta. } & \multirow{2}{*}{ IRI } & \multirow{2}{*}{ Kondisi } & \multirow{2}{*}{ PSI } & Fungsi Pelayanan & \multirow{2}{*}{ RCI } & \multirow{2}{*}{ Kondisi Permukaan } \\
\cline { 2 - 4 } & Awal & Akhir & & & & & & \\
\hline \hline 1 & $0+000$ & $0+100$ & 3.4 & Baik & 2,07 & Cukup & 8,00 & Sangat baik \\
\hline 2 & $0+100$ & $0+200$ & 3.6 & Baik & 1,99 & Kurang & 7,87 & Sangat baik \\
\hline 3 & $0+200$ & $0+300$ & 2.9 & Baik & 2,31 & Cukup & 8,32 & Sangat rata \\
\hline 4 & $0+300$ & $0+400$ & 3.6 & Baik & 1,99 & Kurang & 7,87 & Sangat baik \\
\hline
\end{tabular}




\begin{tabular}{|c|c|c|c|c|c|c|c|c|}
\hline \multirow{2}{*}{ No. } & \multicolumn{2}{|c|}{ Sta. } & \multirow{2}{*}{ IRI } & \multirow{2}{*}{ Kondisi } & \multirow{2}{*}{ PSI } & \multirow{2}{*}{ Fungsi Pelayanan } & \multirow{2}{*}{$\mathrm{RCI}$} & \multirow{2}{*}{ Kondisi Permukaan } \\
\hline & Awal & Akhir & & & & & & \\
\hline 5 & $0+400$ & $0+500$ & 4.6 & Sedang & 1,60 & Turang & 7,24 & Sangat balk \\
\hline 6 & $0+500$ & $0+600$ & 3.4 & Baik & 2,07 & Cukup & 8,00 & Sangat baik \\
\hline 7 & $0+600$ & $0+700$ & 4.3 & Sedang & 1,71 & Kurang & 7,43 & Sangat baik \\
\hline 8 & $0+700$ & $0+800$ & 6.0 & Sedang & 1,13 & Kurang & 6,40 & Baik \\
\hline 9 & $0+800$ & $0+900$ & 3.9 & Baik & 1,86 & Kurang & 7,68 & Sangat baik \\
\hline 10 & $0+900$ & $1+000$ & 3.4 & Baik & 2,07 & Cukup & 8,00 & Sangat baik \\
\hline 11 & $1+000$ & $1+100$ & 3.1 & Baik & 2,21 & Cukup & 8,19 & Sangat rata \\
\hline 12 & $1+100$ & $1+200$ & 3.6 & Baik & 1,99 & Kurang & 7,87 & Sangat baik \\
\hline 13 & $1+200$ & $1+300$ & 3.4 & Baik & 2,07 & Cukup & 8,00 & Sangat baik \\
\hline 14 & $1+300$ & $1+400$ & 3.6 & Baik & 1,99 & Kurang & 7,87 & Sangat baik \\
\hline 15 & $1+400$ & $1+500$ & 3.6 & Baik & 1,99 & Kurang & 7,87 & Sangat baik \\
\hline 16 & $1+500$ & $1+600$ & 7.4 & Sedang & 0,68 & Sangat Kurang & 5,62 & Cukup \\
\hline 17 & $1+600$ & $1+700$ & 4.1 & Sedang & 1,79 & Kurang & 7,55 & Sangat baik \\
\hline 18 & $1+700$ & $1+800$ & 4.6 & Sedang & 1,60 & Kurang & 7,24 & Sangat baik \\
\hline 19 & $1+800$ & $1+900$ & 6.7 & Sedang & 0,91 & Sangat Kurang & 6,00 & Cukup \\
\hline 20 & $1+900$ & $2+000$ & 6.0 & Sedang & 1,13 & Kurang & 6,40 & Baik \\
\hline 21 & $2+000$ & $2+100$ & 5.8 & Sedang & 1,20 & Kurang & 6,52 & Baik \\
\hline 22 & $2+100$ & $2+200$ & 3.9 & Baik & 1,86 & Kurang & 7,68 & Sangat baik \\
\hline 23 & $2+200$ & $2+300$ & 5.3 & Sedang & 1,36 & Kurang & 6,81 & Baik \\
\hline 24 & $2+300$ & $2+400$ & 4.1 & Sedang & 1,79 & Kurang & 7,55 & Sangat baik \\
\hline 25 & $2+400$ & $2+500$ & 4.6 & Sedang & 1,60 & Kurang & 7,24 & Sangat baik \\
\hline 26 & $2+500$ & $2+600$ & 5.3 & Sedang & 1,36 & Kurang & 6,81 & Baik \\
\hline 27 & $2+600$ & $2+700$ & 3.1 & Baik & 2,21 & Cukup & 8,19 & Sangat rata \\
\hline 28 & $2+700$ & $2+800$ & 4.1 & Sedang & 1,79 & Kurang & 7,55 & Sangat baik \\
\hline 29 & $2+800$ & $2+900$ & 2.7 & Baik & 2,42 & Cukup & 8,45 & Sangat rata \\
\hline 30 & $2+900$ & $3+000$ & 4.1 & Sedang & 1,79 & Kurang & 7,55 & Sangat baik \\
\hline 31 & $3+000$ & $3+100$ & 4.3 & Sedang & 1,71 & Kurang & 7,43 & Sangat baik \\
\hline 32 & $3+100$ & $3+200$ & 2.9 & Baik & 2,31 & Cukup & 8,32 & Sangat rata \\
\hline 33 & $3+200$ & $3+300$ & 2.8 & Baik & 2,37 & Cukup & 8,39 & Sangat rata \\
\hline 23 & $2+200$ & $2+300$ & 5.3 & Sedang & 1,99 & Kurang & 6,81 & Baik \\
\hline \multicolumn{3}{|c|}{ Rata-rata } & 4,2 & Sedang & 1,79 & Kurang & 7,51 & Sangat baik \\
\hline
\end{tabular}

Dari rata-rata nilai IRI = 4,2 untuk analisis fungsi pelayanan jalan pada Batas Kota Wates-Milir didapatkan rata-rata nilai PSI sebesar 1,79 yang menyatakan bahwa ruas jalan memiliki kondisi pelayanan yang kurang. Sedangkan rata-rata nilai RCI sebesar 7,51 menyatakan bahwa ruas jalan memiliki kondisi permukaan secara visual yang tergolong sangat baik, pada umumnya rata. Dengan menggunakan data IRI yang sama dapat menghasilkan nilai PSI yang rendah dalam rentang nilai 0-5, namun menghasilkan nilai RCI yang tinggi dalam rentang nilai 2-10. Hal tersebut mengindikasikan bahwa antara nilai PSI dan RCI tidak memiliki korelasi satu sama lain dan keduanya merupakan metode yang berbeda.

\section{Analisis Prediksi Sisa Umur Perkerasan Jalan}

Untuk melakukan prediksi sisa umur perkerasan adalah dengan data lalu lintas. Skenario yang digunakan adalah menggunakan lalu lintas rencana dan lalu lintas aktual. Jenis kendaraan yang digunakan untuk analisis adalah kendaraan yang dapat merusak perkerasan, yaitu kendaraan dengan nilai VDF $\neq 0$. 


\section{1). Lalu Lintas Rencana}

Lalu lintas rencana merupakan lalu lintas yang digunakan sebagai dasar untuk melakukan peningkatan jalan pada tahun 2012. Data lalu lintas yang digunakan adalah mulai tahun 2010 s.d. 2012. Angka pertumbuhan lalu lintas (i) untuk tiap tahun dengan menggunakan persamaan [3]dapat dihitung seperti pada contoh perhitungan berikut.

Untuk jenis kendaraan Bus Kecil (Gol. 5a).

$i_{2011}=\left(\frac{\sum \text { kendaraan } / \text { hari }_{2011}}{\sum \text { kendaraan } / \text { hari }_{2010}}\right)^{\frac{1}{n}}-1$

$i_{2011}=\left(\frac{134}{193}\right)^{\frac{1}{1}}-1$

$i_{2011}=-0,31$

Selanjutnya dihitung angka pertumbuhan rata-rata untuk tahun 2010 s.d. 2012 , apabila nilai $i_{\text {rata-rata }} \leq i_{\text {minimm desain, }}$, maka

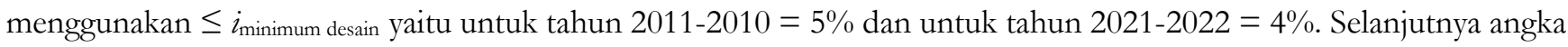
pertumbuhan lalu lintas (i) rencana yang digunakan untuk analisis dapat dilihat pada Tabel 5 berikut.

Tabel 5 Angka Pertumbuhan Lalu Lintas (i) Tahun 2010 s.d. 2012

\begin{tabular}{|c|l|c|c|c|c|c|c|c|c|c|}
\hline \multirow{2}{*}{ No. } & \multirow{2}{*}{ Jenis Kendaraan } & \multirow{2}{*}{ Gol. } & \multicolumn{3}{|c|}{$\sum$ Kendaran/Hari } & \multicolumn{3}{|c|}{$i(\%)$} & \multicolumn{2}{|c|}{$i$ untuk Analisis(\%) } \\
\cline { 4 - 13 } & & & 2010 & 2011 & 2012 & 2011 & 2012 & Rata-rata & $2011-2020$ & $2021-2022$ \\
\hline \hline 1 & Bus Kecil & $5 \mathrm{a}$ & 193 & 134 & 214 & -31 & 60 & 14,78 & \multicolumn{2}{|c|}{14,78} \\
\hline 2 & Bus Besar & $5 \mathrm{~b}$ & 316 & 167 & 218 & -47 & 30 & $-8,25$ & 5,00 & 4,00 \\
\hline 3 & Truck Ringan 2 As & $6 \mathrm{a}$ & 187 & 116 & 200 & -38 & 73 & 17,30 & \multicolumn{2}{|c|}{17,30} \\
\hline 4 & Truck Berat 2 As & 6b & 673 & 352 & 472 & -48 & 34 & $-6,80$ & 5,00 & 4,00 \\
\hline 5 & Truck Berat 3 As & $7 \mathrm{a}$ & 180 & 153 & 145 & -15 & -5 & $-10,05$ & 5,00 & 4,00 \\
\hline 6 & Truck Gandeng 4 As & $7 \mathrm{~b}$ & 58 & 53 & 82 & -9 & 56 & 23,20 & \multicolumn{2}{|c|}{23,20} \\
\hline 7 & Truck Semi Trailer & $7 \mathrm{c}$ & 37 & 40 & 55 & 6 & 39 & 22,92 & \multicolumn{2}{|c|}{22,92} \\
\hline
\end{tabular}

Berdasarkan nilai $i$, kemudian dilakukan prediksi terhadap jumlah lalu lintas selama umur rencana. Data lalu lintas awal adalah lalu lintas tahun 2012 (tahun dilakukan overlay), contoh perhitungan adalah sebagai berikut.

Prediksi jumlah kendaraan/hari untuk Bus Kecil (Gol. 5a) dengan nilai $i=14,78 \%$ menggunakan persamaan [4

$\sum$ kendaraan ${ }_{2013}=\sum$ kendaraan $/$ hari $_{2012} \times(1+i)^{\mathrm{n}}$

$\sum$ kendaraan $_{2013}=214 \times(1+0,1478)^{1}$

$\sum$ kendaraan $_{2013}=246$

Selanjutnya perhitungan prediksi jumlah kendaraan untuk masing-masing golongan selama umur rencana ditampilkan dalam Tabel 6 Prediksi Lalu Lintas Rencana sebagai berikut.

Tabel 6 Prediksi Lalu Lintas Rencana

\begin{tabular}{|c|l|c|c|c|c|c|c|c|c|c|c|c|c|}
\hline \multirow{2}{*}{ No. } & \multirow{2}{*}{ Jenis Kendaraan } & \multirow{2}{*}{ Gol. } & \multicolumn{10}{|c|}{ Kendaraan/Hari } \\
\cline { 4 - 15 } & & & 2012 & 2013 & 2014 & 2015 & 2016 & 2017 & 2018 & 2019 & 2020 & 2021 & 2022 \\
\hline \hline 1 & Bus Kecil & $5 \mathrm{a}$ & 214 & 246 & 282 & 324 & 372 & 427 & 490 & 562 & 645 & 741 & 850 \\
\hline 2 & Bus Besar & $5 \mathrm{~b}$ & 218 & 229 & 241 & 253 & 265 & 279 & 293 & 307 & 323 & 336 & 323 \\
\hline 3 & Truck Ringan 2 As & $6 \mathrm{a}$ & 200 & 234 & 275 & 322 & 378 & 444 & 520 & 610 & 716 & 840 & 985 \\
\hline 4 & Truck Berat 2 As & $6 \mathrm{~b}$ & 472 & 495 & 520 & 546 & 573 & 602 & 632 & 664 & 697 & 725 & 698 \\
\hline 5 & Truck Berat 3 As & $7 \mathrm{a}$ & 145 & 152 & 160 & 168 & 176 & 185 & 195 & 204 & 215 & 223 & 215 \\
\hline 6 & Truck Gandeng 4 As & $7 \mathrm{~b}$ & 82 & 101 & 125 & 154 & 189 & 233 & 287 & 354 & 436 & 538 & 662 \\
\hline 7 & Truck Semi Trailer & $7 \mathrm{c}$ & 55 & 68 & 83 & 103 & 126 & 155 & 190 & 234 & 288 & 354 & 435 \\
\hline
\end{tabular}


Dari prediksi jumlah kendaraan/hari selama umur rencana selanjutnya dilakukan perhitungan nilai ESAL, Wt kumulatif selama umur rencana dan umur sisa perkerasan jalan (Remaining Life) sebagai berikut.

Untuk Bus Kecil (Gol. 5a) tahun 2013 dengan prediksi jumlah kendaraan/hari sebesar 246 dan nilai VDF berdasarkan Tabel 3 adalah 0,30, maka perhitungan jumlah ESAL berdasarkan persamaan [5] adalah sebagai berikut.

$\mathrm{ESAL}=\sum$ Kendaraan $_{\mathrm{i}} \times \mathrm{E}_{\mathrm{i}}$

$\mathrm{ESAL}=246 \times 0,30$

$\mathrm{ESAL}=74$

Selanjutnya perhitungan perhitungan ESAL untuk masing-masing golongan selama umur rencana ditampilkan dalam Tabel 7 ESAL Rencana berikut.

Tabel 7 ESAL Rencana

\begin{tabular}{|c|c|c|c|c|c|c|c|c|c|c|c|c|}
\hline \multirow{2}{*}{ No. } & \multirow{2}{*}{ Jenis Kendaraan } & \multirow{2}{*}{ Gol. } & \multicolumn{10}{|c|}{ ESAL } \\
\hline & & & 2013 & 2014 & 2015 & 2016 & 2017 & 2018 & 2019 & 2020 & 2021 & 2022 \\
\hline 1 & Bus Kecil & $5 a$ & 74 & 85 & 97 & 112 & 128 & 147 & 169 & 194 & 222 & 255 \\
\hline 2 & Bus Besar & $5 b$ & 229 & 241 & 253 & 265 & 279 & 293 & 307 & 323 & 336 & 323 \\
\hline 3 & Truck Ringan 2 As & $6 a$ & 187 & 220 & 258 & 303 & 355 & 416 & 488 & 573 & 672 & 788 \\
\hline 4 & Truck Berat 2 As & $6 \mathrm{~b}$ & 3.615 & 3.796 & 3.985 & 4.185 & 4.394 & 4.614 & 4.844 & 5.086 & 5.290 & 5.096 \\
\hline 5 & Truck Berat 3 As & $7 a$ & 4.406 & 4.626 & 4.858 & 5.101 & 5.356 & 5.623 & 5.905 & 6.200 & 6.448 & 6.212 \\
\hline 6 & Truck Gandeng 4 As & $7 b$ & 3.737 & 4.604 & 5.672 & 6.988 & 8.610 & 10.607 & 13.068 & 16.100 & 19.836 & 24.438 \\
\hline 7 & Truck Semi Trailer & $7 \mathrm{c}$ & 923 & 1.134 & 1.394 & 1.714 & 2.107 & 2.590 & 3.183 & 3.913 & 4.810 & 5.913 \\
\hline & Total & & 13.171 & 14.706 & 16.518 & 18.667 & 21.228 & 24.290 & 27.965 & 32.389 & 37.613 & 43.025 \\
\hline
\end{tabular}

Lalu lintas pada lajur rencana selama satu tahun dihitung dalam beban gandar standar kumulatif $\left(\mathrm{W}_{\mathrm{t}}\right)$ berdasarkan persamaan [6] dengan nilai $\mathrm{D}_{\mathrm{D}}=0,5$ dan $\mathrm{D}_{\mathrm{L}}=0,8$. Contoh perhitungan $\mathrm{W}_{\mathrm{t}}$ adalah sebagai berikut.

$$
\begin{array}{ll}
\mathrm{W}_{\mathrm{t} 2013} & =\mathrm{ESAL} \times \mathrm{D}_{\mathrm{D}} \times \mathrm{D}_{\mathrm{L}} \times 365 \\
\mathrm{~W}_{\mathrm{t} 2013} & =13.171 \times 0,5 \times 0,8 \times 365 \\
\mathrm{~W}_{\mathrm{t} 2013} & =1.922 .997 \mathrm{ESAL} \\
\mathrm{W}_{\mathrm{t} \text { kumulatif 2013 }} & =\mathrm{W}_{\mathrm{t} 2013} \\
\mathrm{~W}_{\mathrm{t} \text { kumulatif 2013 }} & =1.922 .997 \mathrm{ESAL} \\
\mathrm{W}_{\mathrm{t} 2014} & =\mathrm{ESAL} \times \mathrm{D}_{\mathrm{D}} \times \mathrm{D}_{\mathrm{L}} \times 365 \\
\mathrm{~W}_{\mathrm{t} 2014} & =14.706 \times 0,5 \times 0,8 \times 365 \\
\mathrm{~W}_{\mathrm{t} 2014} & =2.147 .021 \mathrm{ESAL} \\
\mathrm{W}_{\mathrm{t} \text { kumulatif } 2014} & =\mathrm{W}_{\mathrm{t} 2013}+\mathrm{W}_{\mathrm{t} 2014} \\
\mathrm{~W}_{\mathrm{t} \text { kumulatif } 2014} & =1.922 .997+2.147 .021 \mathrm{ESAL} \\
\mathrm{W}_{\mathrm{t} \text { kumulatif 2014 }} & =4.070 .018 \mathrm{ESAL}
\end{array}
$$

Selanjutnya perhitungan perhitungan $\mathrm{W}_{\mathrm{t}}$ kumulatif selama umur rencana ditampilkan dalam Tabel 8 .

Perhitungan prediksi sisa umur perkerasan berdasarkan persamaan [7] adalah sebagai berikut.

$$
\begin{aligned}
\mathrm{RL}_{2013} & =100\left[1-\left(\frac{\mathrm{N}_{\mathrm{p}}}{\mathrm{N}_{2}}\right)\right]^{*} \\
\mathrm{RL}_{2013} & =100\left[1-\left(\frac{1.922 .997}{36.437 .342}\right)\right] \\
\mathrm{RL}_{2013} & =94,72 \% \\
{ }^{*} \mathrm{~N}_{\mathrm{p}} & =\text { Kumulatif } \mathrm{W}_{\mathrm{t}} \text { pada tahun } \mathrm{i} \\
\mathrm{N}_{2} & =\text { Kumulatif } \mathrm{W}_{\mathrm{t}} \text { pada akhir tahun rencana }
\end{aligned}
$$


Selanjutnya perhitungan prediksi sisa umur perkerasan untuk lalu lintas rencana ditampilkan pada Tabel $8 \mathrm{Wt}$ Kumulatif Rencana dan Remaining Life berikut.

Tabel $8 \mathrm{~W}_{\mathrm{t}}$ Kumulatif Rencana dan Remaining Life

\begin{tabular}{|c|c|c|c|c|}
\hline UR & Tahun & $\mathrm{W}_{\mathrm{t}}$ & $\mathrm{W}_{\mathrm{t}}$ Kumulatif & Remaining Life $(\%)$ \\
\hline \hline 1 & 2013 & 1.922 .997 & 1.922 .997 & 94,72 \\
\hline 2 & 2014 & 2.147 .021 & 4.070 .018 & 88,83 \\
\hline 3 & 2015 & 2.411 .560 & 6.481 .578 & 82,21 \\
\hline 4 & 2016 & 2.725 .379 & 9.206 .957 & 74,73 \\
\hline 5 & 2017 & 3.099 .233 & 12.306 .190 & $\underline{66,23}$ \\
\hline 6 & 2018 & 3.546 .322 & 15.852 .512 & 56,49 \\
\hline 7 & 2019 & 4.082 .861 & 19.935 .373 & 45,29 \\
\hline 8 & 2020 & 4.728 .766 & 24.664 .139 & 32,31 \\
\hline 9 & 2021 & 5.491 .560 & 30.155 .699 & 17,24 \\
\hline 10 & 2022 & 6.281 .642 & 36.437 .342 & 0,00 \\
\hline
\end{tabular}

Dari perhitungan didapatkan hasil nilai $\mathrm{W}_{\mathrm{t}}$ kumulatif saat akhir umur rencana yaitu sebesar 36.437.342 ESAL.

\section{2). Lalu Lintas Aktual}

Lalu lintas aktual merupakan lalu lintas yang melewati jalan setelah dilakukan peningkatan pada tahun 2012. Data lalu lintas yang digunakan adalah data lalu lintas mulai tahun 2012 sampai dengan tahun 2016. Contoh perhitungan angka pertumbuhan lalu lintas (i) aktual untuk jenis kendaraan Bus Kecil (Gol. 5a) tahun 2013 menggunakan persamaan [3] sebagai berikut.

$i_{2013}=\left(\frac{\sum \text { kendaraan } / \text { hari }_{2013}}{\sum \text { kendaraan } / \text { hari }_{2012}}\right)^{\frac{1}{n}}-1$

$i_{2013}=\left(\frac{135}{214}\right)^{\frac{1}{1}}-1$

$i_{2013}=-0,37$

Selanjutnya dihitung angka pertumbuhan rata-rata untuk tahun 2012 s.d. 2016 yang dapat dilihar pada Tabel 9 Angka Pertumbuhan Lalu Lintas (i) Tahun 2012 s.d. 2016 berikut.

Tabel 9 Angka Pertumbuhan Lalu Lintas (i) Tahun 2012 s.d. 2016

\begin{tabular}{|c|l|c|c|c|c|c|c|c|c|c|c|c|}
\hline \multirow{2}{*}{ No. } & \multirow{2}{*}{ Jenis Kendaraan } & \multirow{2}{*}{ Gol. } & \multicolumn{4}{|c|}{$\sum$ Kendaraan/Hari } & \multicolumn{5}{|c|}{$i(\%)$} \\
\cline { 4 - 14 } & & & 2012 & 2013 & 2014 & 2015 & 2016 & 2013 & 2014 & 2015 & 2016 & Rata-rata \\
\hline \hline 1 & Bus Kecil & $5 \mathrm{a}$ & 214 & 135 & 135 & 185 & 427 & -37 & 0 & 37 & 130 & 32,61 \\
\hline 2 & Bus Besar & $5 \mathrm{~b}$ & 218 & 272 & 272 & 346 & 758 & 24 & 0 & 27 & 119 & 42,72 \\
\hline 3 & Truck Ringan 2 As & 6a & 200 & 227 & 227 & 290 & 653 & 14 & 0 & 28 & 125 & 41,64 \\
\hline 4 & Truck Berat 2 As & 6b & 472 & 713 & 713 & 844 & 1,849 & 51 & 0 & 18 & 119 & 47,16 \\
\hline 5 & Truck Berat 3 As & $7 \mathrm{a}$ & 145 & 112 & 112 & 163 & 393 & -23 & 0 & 45 & 141 & 40,88 \\
\hline 6 & Truck Gandeng 4 As & $7 \mathrm{~b}$ & 82 & 71 & 71 & 112 & 280 & -14 & 0 & 58 & 151 & 48,71 \\
\hline 7 & Truck Semi Trailer & $7 \mathrm{c}$ & 55 & 64 & 64 & 116 & 287 & 16 & 0 & 81 & 147 & 61,13 \\
\hline
\end{tabular}

Berdasarkan nilai $i$ untuk masing-masing jenis kendaraan, kemudian dilakukan prediksi terhadap jumlah lalu lintas aktual selama umur rencana menggunakan persamaan [4]. Contoh perhitungan jumlah kendaraan/hari untuk jenis kendaraan Bus Kecil (Gol. 5a) adalah sebagai berikut.

$\sum$ kendaraan $_{2013}=\sum$ kendaraan $/$ hari $_{2012} \times(1+i)^{\mathrm{n}}$ 
$\sum_{\text {kendaraan }} 2013=214 \times(1+0,3261)^{1}$

$\sum$ kendaraan $_{2013}=284$

Selanjutnya perhitungan prediksi lalu lintas aktual dapat dilihat pada Tabel 10 Prediksi Lalu Lintas Aktual berikut.

Tabel 10 Prediksi Lalu Lintas Aktual

\begin{tabular}{|c|l|c|c|c|c|c|c|c|c|c|c|c|c|}
\hline \multirow{2}{*}{ No. } & \multirow{2}{*}{ Jenis Kendaraan } & \multirow{2}{*}{ Gol. } & \multicolumn{10}{|c|}{ Kendaraan/Hari } \\
\cline { 4 - 15 } & & & 2012 & 2013 & 2014 & 2015 & 2016 & 2017 & 2018 & 2019 & 2020 & 2021 & 2022 \\
\hline \hline 1 & Bus Kecil & $5 \mathrm{a}$ & 214 & 284 & 377 & 500 & 662 & 879 & 1.165 & 1.545 & 2.049 & 2.717 & 3.603 \\
\hline 2 & Bus Besar & $5 \mathrm{~b}$ & 218 & 312 & 445 & 635 & 906 & 1.293 & 1.846 & 2.634 & 3.759 & 5.365 & 7.657 \\
\hline 3 & Truck Ringan 2 As & $6 \mathrm{a}$ & 200 & 283 & 401 & 568 & 804 & 1.139 & 1.613 & 2.285 & 3.236 & 4.584 & 6.492 \\
\hline 4 & Truck Berat 2 As & $6 \mathrm{~b}$ & 472 & 694 & 1.021 & 1.503 & 2.212 & 3.255 & 4.790 & 7.050 & 10.375 & 15.268 & 22.469 \\
\hline 5 & Truck Berat 3 As & $7 \mathrm{a}$ & 145 & 205 & 288 & 406 & 572 & 806 & 1.135 & 1.600 & 2.254 & 3.175 & 4.473 \\
\hline 6 & Truck Gandeng 4 As & $7 \mathrm{~b}$ & 82 & 122 & 182 & 270 & 402 & 598 & 889 & 1.322 & 1.966 & 2.923 & 4.347 \\
\hline 7 & Truck Semi Trailer & $7 \mathrm{c}$ & 55 & 89 & 143 & 231 & 372 & 600 & 966 & 1.557 & 2.508 & 4.041 & 6.512 \\
\hline
\end{tabular}

Selanjutnya dilakukan perhitungan nilai ESAL menggunakan persamaan [5]. Contoh perhitungan jumlah ESAL aktual untuk Bus Kecil (Gol. 5a) tahun 2013 adalah sebagai berikut.

$\mathrm{ESAL}=\sum$ Kendaraan $_{\mathrm{i}} \times \mathrm{E}_{\mathrm{i}}$

$\mathrm{ESAL}=284 \times 0,30$

$\mathrm{ESAL}=85$

Selanjutnya hasil perhitungan nilai ESAL actual selama umur rencana dapat dilihat pada Tabel 11 ESAL Aktual berikut.

Tabel 11 ESAL Aktual

\begin{tabular}{|c|c|c|c|c|c|c|c|c|c|c|c|c|}
\hline \multirow{2}{*}{ No. } & \multirow{2}{*}{ Jenis Kendaraan } & \multirow{2}{*}{ Gol. } & \multicolumn{10}{|c|}{ ESAL } \\
\hline & & & 2013 & 2014 & 2015 & 2016 & 2017 & 2018 & 2019 & 2020 & 2021 & 2022 \\
\hline 1 & Bus Kecil & $5 a$ & 85 & 113 & 150 & 199 & 264 & 350 & 464 & 615 & 815 & 1.081 \\
\hline 2 & Bus Besar & $5 b$ & 312 & 445 & 635 & 906 & 1.293 & 1.846 & 2.634 & 3.759 & 5.365 & 7.657 \\
\hline 3 & Truck Ringan 2 As & $6 a$ & 226 & 321 & 454 & 643 & 911 & 1.290 & 1.828 & 2.589 & 3.667 & 5.194 \\
\hline 4 & Truck Berat 2 As & $6 \mathrm{~b}$ & 5.066 & 7.456 & 10.972 & 16.147 & 23.763 & 34.970 & 51.464 & 75.736 & 111.456 & 164.022 \\
\hline 5 & Truck Berat 3 As & $7 \mathrm{a}$ & 5.912 & 8.329 & 11.734 & 16.531 & 23.290 & 32.812 & 46.227 & 65.127 & 91.753 & 129.265 \\
\hline 6 & Truck Gandeng 4 As & $7 \mathrm{~b}$ & 4.511 & 6.708 & 9.975 & 14.833 & 22.059 & 32.803 & 48.781 & 72.541 & 107.875 & 160.419 \\
\hline 7 & Truck Semi Trailer & $7 c$ & 1.210 & 1.949 & 3.141 & 5.060 & 8.154 & 13.138 & 21.170 & 34.111 & 54.962 & 88.561 \\
\hline \multicolumn{3}{|c|}{ Total } & 17.322 & 25.320 & 37.061 & 54.321 & 79.733 & 117.209 & 172.566 & 254.477 & 375.892 & 556.198 \\
\hline
\end{tabular}

Lalu lintas pada lajur rencana selama satu tahun dihitung dalam beban gandar standar kumulatif $\left(\mathrm{W}_{\mathrm{t}}\right)$ berdasarkan persamaan [6] dengan nilai $\mathrm{D}_{\mathrm{D}}=0,5$ dan $\mathrm{D}_{\mathrm{L}}=0,8$. Contoh perhitungan $\mathrm{W}_{\mathrm{t}}$ adalah sebagai berikut.

$\mathrm{W}_{\mathrm{t} 2013}=\mathrm{ESAL} \times \mathrm{D}_{\mathrm{D}} \times \mathrm{D}_{\mathrm{L}} \times 365$

$\mathrm{W}_{\mathrm{t} 2013}=17.322 \times 0,5 \times 0,8 \times 365$

$\mathrm{W}_{\mathrm{t} 2013}=2.528 .983 \mathrm{ESAL}$

$\mathrm{W}_{\mathrm{t} \text { kumulatif 2013 }}=\mathrm{W}_{\mathrm{t} 2013}$

$\mathrm{W}_{\mathrm{t} \mathrm{kumulatif} 2013}=2.528 .983 \mathrm{ESAL}$

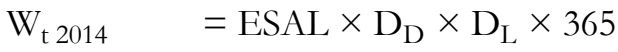

$\mathrm{W}_{\mathrm{t} 2014}=25.320 \times 0,5 \times 0,8 \times 365$

$\mathrm{W}_{\mathrm{t} 2014=3.696 .721 \mathrm{ESAL}}$

$\mathrm{W}_{\mathrm{t} \text { kumulatif } 2014}=\mathrm{W}_{\mathrm{t} 2013}+\mathrm{W}_{\mathrm{t} 2014}$

$\mathrm{W}_{\mathrm{t} \text { kumulatif } 2014}=2.528 .983+3.696 .721$ 
$\mathrm{W}_{\mathrm{t} \mathrm{kumulatif} 2014}=6.225 .703 \mathrm{ESAL}$

Selanjutnya perhitungan perhitungan $\mathrm{W}_{\mathrm{t}}$ kumulatif selama umur rencana ditampilkan dalam Tabel 12 Kumulatif Aktual dan Remaining Life.

Perhitungan prediksi sisa umur perkerasan berdasarkan persamaan [7] adalah sebagai berikut.

$$
\begin{aligned}
\mathrm{RL}_{2013}= & 100\left[1-\left(\frac{\mathrm{N}_{\mathrm{p}}}{\mathrm{N}_{2}}\right)\right]^{*} \\
\mathrm{RL}_{2013}= & 100\left[1-\left(\frac{2.528 .983}{36.437 .342}\right)\right] \\
\mathrm{RL}_{2013}= & 93,06 \% \\
{ }^{*} \mathrm{~N}_{\mathrm{p}}= & \text { Kumulatif } \mathrm{W}_{\mathrm{t}} \text { pada tahun } \mathrm{i} \\
\mathrm{N}_{2}= & \text { Kumulatif } \mathrm{W}_{\mathrm{t}} \text { pada akhir tahun perencanaan awal } \\
& \mathrm{W}_{\mathrm{t}} \text { kumulatif rencana adalah sebesar 36.437.342 ESAL }
\end{aligned}
$$

Selanjutnya perhitungan prediksi sisa umur perkerasan untuk lalu lintas rencana ditampilkan pada Tabel $12 \mathrm{~W}_{t}$ Kumulatif Aktual dan Remaining Life berikut.

Tabel $12 \mathrm{~W}_{\mathrm{t}}$ Kumulatif Aktual dan Remaining Life

\begin{tabular}{|c|c|c|c|c|}
\hline UR & Tahun & $\mathrm{W}_{\mathrm{t}}$ & $\mathrm{W}_{\mathrm{t}}$ Kumulatif & Remaining Life (\%) \\
\hline \hline 1 & 2013 & 2.528 .983 & 2.528 .983 & 93,06 \\
\hline 2 & 2014 & 3.696 .721 & 6.225 .703 & 82,91 \\
\hline 3 & 2015 & 5.410 .865 & 11.636 .568 & 68,06 \\
\hline 4 & 2016 & 7.930 .812 & 19.567 .380 & 46,30 \\
\hline 5 & 2017 & 11.641 .057 & 31.208 .437 & $\underline{14,35}$ \\
\hline 6 & 2018 & 17.112 .545 & 48.320 .982 & $-32,61$ \\
\hline 7 & 2019 & 25.194 .684 & 73.515 .666 & $-101,76$ \\
\hline 8 & 2020 & 37.153 .594 & 110.669 .260 & $-203,72$ \\
\hline 9 & 2021 & 54.880 .299 & 165.549 .559 & $-354,34$ \\
\hline 10 & 2022 & 81.204 .947 & 246.754 .506 & $-577,20$ \\
\hline
\end{tabular}

Dari hasil analisis dinyatakan bahwa lalu lintas aktual jauh lebih besar daripada lalu lintas yang rencana sehingga umur perkerasan akibat besarnya lalu lintas aktual diprediksi akan berakhir pada tahun ke 6 yaitu pada tahun 2018 dengan prosentase umur sisa sebesar 14,35\% pada tahun 2017.

Berdasarkan hasil analisis sampai dengan tahun 2017 untuk lalu lintas rencana dan lalu lintas aktual, didapatkan penurunan sisa umur perkerasan sesuai Tabel 13 Perbandingan Umur Sisa Perkerasan (Remaining Life) Tahun 2017 sebagai berikut.

Tabel 13 Perbandingan Umur Sisa Perkerasan (Remaining Life) Tahun 2017

\begin{tabular}{|c|l|c|c|}
\hline No. & \multicolumn{1}{|c|}{ Lalu Lintas } & Remaining Life (\%) & Penurunan Umur Rencana (\%) \\
\hline \hline 1 & Rencana & 66,23 & - \\
\hline 2 & Aktual & 14,35 & 51,88 \\
\hline
\end{tabular}

Penurunan sisa umur perkerasan akibat lalu lintas aktual $=\mathrm{RL}_{\text {rencana }}-\mathrm{RL}_{\text {aktual }}$

$$
\begin{aligned}
& =66,23-14,35 \\
& =51,88 \%
\end{aligned}
$$

Perhitungan kumulatif ESAL selama umur rencana disajikan dalam bentuk Grafik Kumulatif ESAL seperi pada Gambar 2 berikut. 


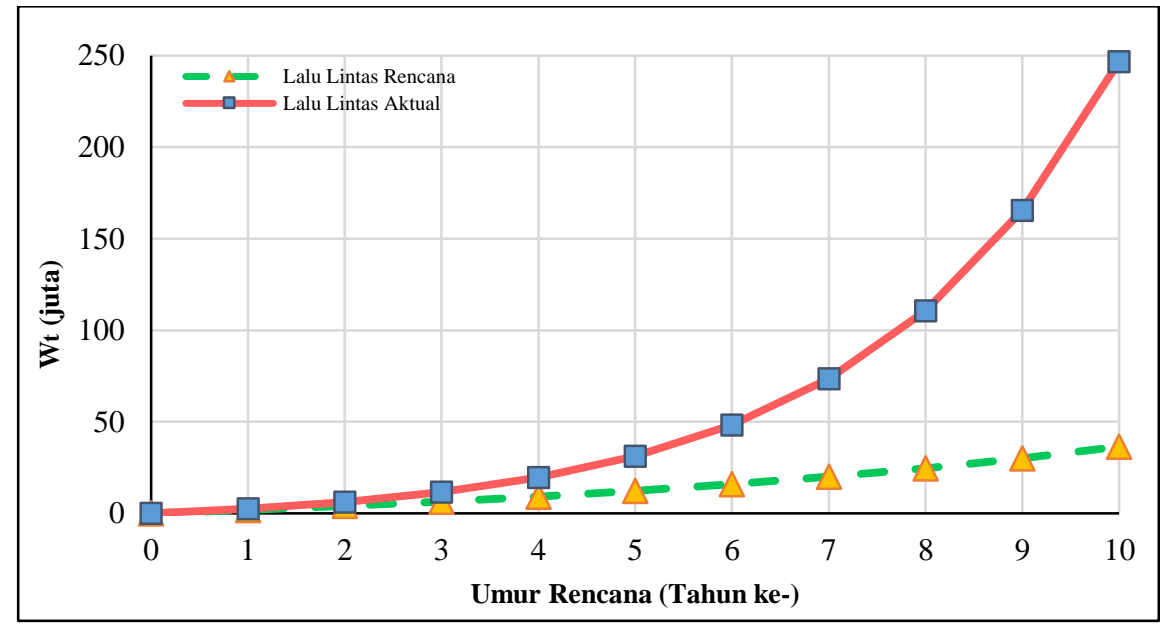

Gambar 2 Kumulatif ESAL Selama Umur Rencana

Grafik perbandingan prosentase sisa umur perkerasan dari tahun 2012 sampai dengan tahun 2022 untuk lalu lintas rencana dan lalu lintas aktual adalah seperti pada Gambar 3 berikut.

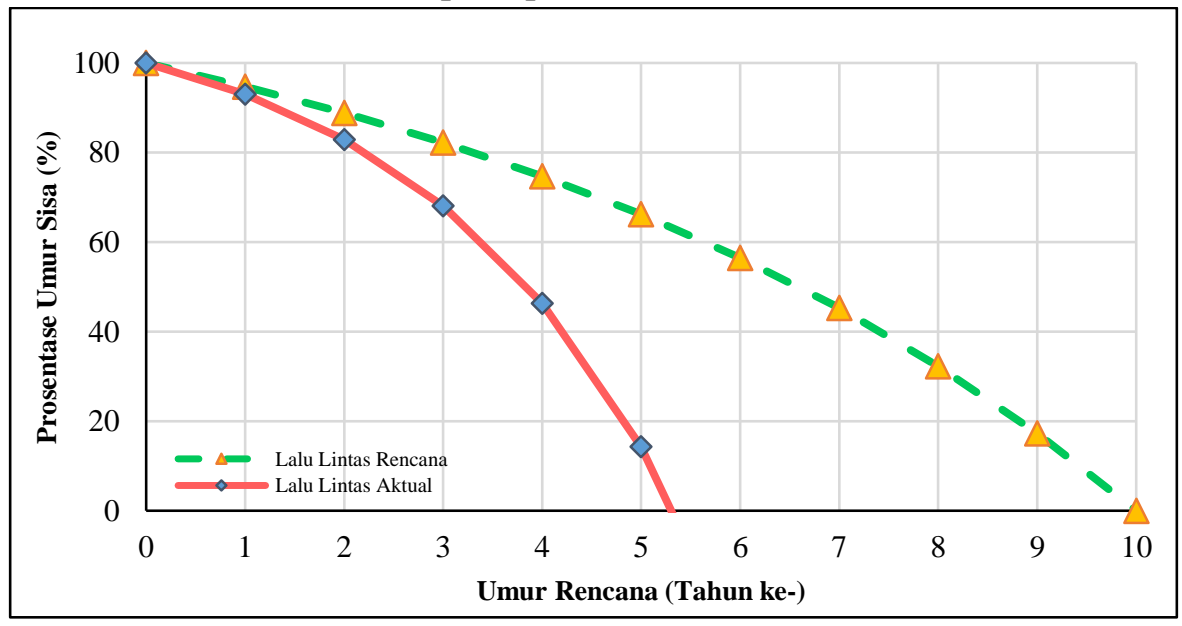

Gambar 3 Grafik Sisa Umur Perkerasan

Dari analisis prediksi sisa umur perkerasan didapatkan hasil bahwa untuk tahun 2017, perkerasan jalan masih memiliki prosentase umur sisa sebesar 14,35\% dan umur perkerasan diprediksikan akan berakhir pada tahun ke 6 yaitu pada tahun 2018, atau 4 tahun lebih cepat dari umur rencana akhir perkerasan yaitu pada tahun 2022 .

\section{KESIMPULAN}

Dari analisis data yang dilakukan pada ruas jalan Batas Kota Wates-Milir Sta 0+000 s.d. Sta. 3+300 dapat diambil kesimpulan sebagai berikut.

a. Dari analisis kondisi fungsional jalan dengan rata-rata nilai IRI $=4,2$ menunjukkan fungsi pelayanan jalan dalam kategori kurang yaitu dengan rata-rata nilai PSI $=1,79$. Sedangkan hasil kondisi permukaan secara visual sangat baik dan pada umumnya rata yang ditunjukkan dengan rata-rata nilai $\mathrm{RCI}=7,51$.

b. Untuk prosentase sisa umur perkerasan pada tahun 2017 adalah sebesar 14,35\% dan umur perkerasan diprediksikan mencapai ESAL rencana pada tahun ke 6 yaitu pada tahun 2018.

\section{REKOMENDASI}


Setelah dilakukan analisis, pembahasan, dan didapatkan kesimpulan dari kondisi fungsional jalan menggunakan metode PSI dan RCI serta prediksi sisa umur perkerasan maka dapat disampaikan bahwa kondisi data pertumbuhan lalu lintas yang terlihat tidak wajar (jauh lebih besar daripada pertumbuhan lalu lintas yang umum terjadi di Indonesia) perlu dicermati. Untuk itu penelitian selanjutnya perlu melakukan survei volume lalu lintas pada ruas jalan yang ditinjau, daripada menggunakan data sekunder.

\section{REFERENSI}

Bidang Perencanaan. (2013). Training Penggunaan Alat Survey IRMS SNVT P2JN Provinsi Bengkulu. https://balai3.wordpress.com/2011/06/11/training-penggunaan-alat-survey-irms-snvt-p2jn-provinsibengkulu/. Diakses 29 April 2017

Bina Marga. (2013). Manual Desain Perkerasan Jalan No. 02/M/BM/2013. Departemen Pekerjaan Umum Direktorat Jendral Bina Marga, Jakarta.

Departemen Permukiman dan Prasarana Wilayah. (2002). Pedoman Perencanaan Tebal Perkerasan Lentur Pt T-01-2002-B. Jakarta.

Jurusan Teknik Sipil Fakultas Teknik UNS. 2012. Buku Pedoman Penulisan Skripsi/Tugas Akbir. Depository Jurusan Teknik Sipil, Fakultas Teknik, Universitas Sebelas Maret Surakarta.

Morisca, W. (2014). Evaluasi Beban Kendaraan Terbadap Derajat Kerusakan dan Umur Sisa Jalan (Studi Kasus: PPT. Simpang Nibung dan PPT. Merapi, Sumatera Selatan). Jurnal Teknik Sipil dan Lingkungan, 2(4), pp-692.

Nainggolan, Jolis (2015). Evaluasi Kondisi Perkerasan Lentur dan Prediksi Umur Layan Jalintim Provinsi Sumatera Selatan (Studi Kasus: Ruas Batas Prov. Jambi - Peninggalan). Jurnal Teknik Sipil, Magister Teknik Sipil Universitas Sebelas Maret Surakarta.

NCHRP. (2001). Rehabilitation Strategies for Highway Pavements. Transportation Research Board (TRB) of the National Research Council. Washington.

Pemerintah Republik Indonesia. (1993). Peraturan Pemerintah Nomor 43 Tabun 1993 tentang Prasarana dan Lalu Lintas Jalan. Jakarta.

Purwingga, Enji P. Evaluasi Kerusakan Dini Akibat Beban Berlebih Pada Perkerasan Lentur (Studi Kasus Ruas Jalan Kartasura Batas Kota Klaten Km 11+900-Km 12+ 300). Skripsi. Universitas Muhammadiyah Surakarta.

Republik Indonesia. (2004). Undang-Undang No 38 Tabun 2004 tentang Jalan. Jakarta: Kementrian Hukum dan Hak Asasi Manusia.

Republik Indonesia. (2009). Undang-Undang No 22 Tabun 2009 tentang Lalu Lintas dan Angkutan Jalan. Jakarta: Kementrian Hukum dan Hak Asasi Manusia.

Setyowati, S. (2011). Penilaian kondisi Perkerasan dengan Metoge Pavement Condition Index (PCI), Peningkatan jalan dan Perbitungan rencana Anggaran Biaya Pada Ruas Jalan Solo Karanganyar Km 4+ 400-11+ 050. Surakarta: Universitas Sebelas Maret Surakarta.

Siahaan, Doan A. (2014). Analisis Perbandingan Nilai Iri Berdasarkan Variasi Rentang Pembacaan Naasra. Jurnal Teknik Sipil Universitas Sumatera Utara.

Suherman, S. (2009). Studi Persamaan Korelasi Antara Ketidakrataan Permukaan Jalan Dengan Indeks Kondisi Jalan Studi Kasus Ruas Jalan Labuan-Cibaliung. Jurnal Teknik Sipil Universitas Atma Jaya Yogyakarta.

Sukirman, S. (1999). Perkerasan Lentur Jalan Raya. Bandung: Nova.

Suriyatno, S. (2016). Analisis Tebal Lapis Tambah dan Umur Sisa Perkerasan Akibat Beban Berlebih Kendaraan (Studi Kasus Ruas Jalan Nasional di Provinsi Sumatera Barat). Doctoral Dissertation Universitas Andalas.

Suswandi, Agus., Sartono Wardhani, dan Hary Christady. (2009). Evaluasi Tingkat Kerusakan Jalan Dengan Methode Pavement Condition Index (PCI) untuk Menunjang Pengambilan Keputusan (Studi Kasus: Jalan Lingkar Selatan, Yogyakarta). Civil Engineering Forum Teknik Sipil.

Syafriana, dkk. (2015). Evaluasi Umur Layan Jalan Dengan Memperbitungkan Beban Berlebih Di Ruas Jalan Lintas Timur Provinsi Aceh. Jurnal Transportasi 15.2. 
Utama, Rangga M., dan Ida Farida. (2016). Evaluasi Kondisi Struktural Pada Jalan Berdasarkan Hubungan Antara Ketidakrataan Permukaan Jalan (IRI) dan Indeks Kondisi Jalan (RCI) (Studi Kasus Ruas Jalan Selajambe-Cibogo-Cibeet, Cianjur). Jurnal Konstruksi 14.1.

Wibowo, Hadi B. (2014). Kegiatan Pemutakbiran Data Jalan Dan Jembatan. http://hadiberantaswibowo.blogspot.co.id/2014/09/. Diakses 22 Juli 2017

Wicaksono, Andyas N. (2016). Evaluasi Perencanaan Tebal Lapis Tambah Metode PD-T-05-2005-B dan Metode SPDJL Menggunakan Program Kenpave pada Jalan Nasional di Yogyakarta. Surakarta: Universitas Sebelas Maret Surakarta. 